\title{
Influence of Feeding Rice DDGS and Mixture of Wheat Straw and Groundnut Straw on Growth, Feed Intake and Thyroid Hormone Profile of Growing Crossbred Heifers
}

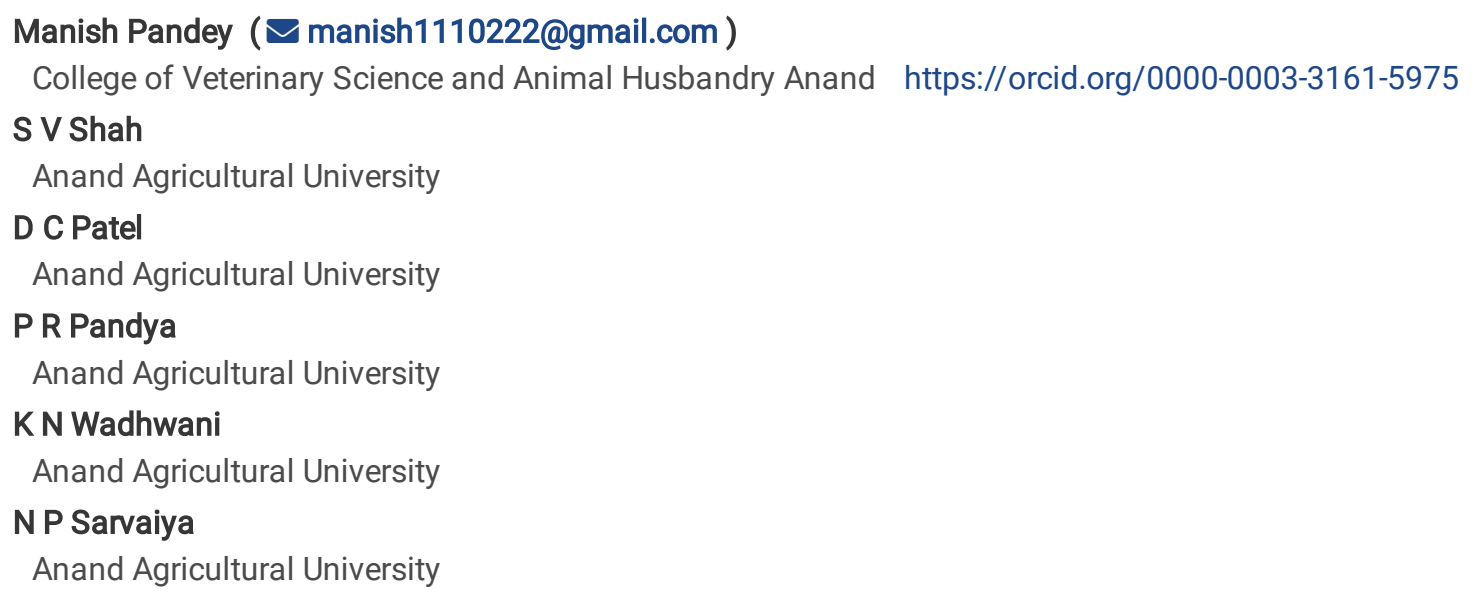

Research Article

Keywords: Rice DDGS, Groundnut straw, Crossbred heifers, Growth, Thyroid hormone

Posted Date: September 9th, 2021

DOI: https://doi.org/10.21203/rs.3.rs-822836/v1

License: (c) (1) This work is licensed under a Creative Commons Attribution 4.0 International License. Read Full License 


\section{Abstract}

Present experiment was carried out at Livestock Research Station, CVSc \& AH, AAU, Anand, Gujarat (India) on twenty-four HFxKankrej heifers with average body weight of $116.13 \pm 4.74 \mathrm{~kg}$ and an average age of $281.92 \pm 13.26$ days to study the effect of feeding rice DDGS and mixture of wheat straw and groundnut straw on growth, feed intake and thyroid hormone profile of growing crossbred heifers. Three different concentrates containing 0,20 and 40\% rice DDGS (RDDGS) were offered to T1, T2 and T3 group heifers, respectively. RDDGS was given in place of soyaDOC in concentrate. Under each concentrate type, half of the heifers were offered wheat straw (R1 group) and another half a mixture of wheat straw and groundnut straw (R2 group) as dry roughage. The protein requirement of heifers was fulfilled as per ICAR (2013). Body weight was recorded at start and then at fortnightly, feed intake was calculated from the records of daily feed consumption and thyroid hormone profile was done in serum samples collected at start and then at 28 days interval throughout the experiment. Prior permission was taken from institutional animal ethics committee (IAEC, Project: 313/LPM/2019). The recorded data during the experiment was statistically analyzed by RBD factorial design. When roughage source was ignored, body weight of T3 group heifers was found significantly $(p<0.05)$ higher compared to T1 and T2 group heifers $(182.32 \pm 4.60 v s .177 .54 \pm 4.63 \& 178.99 \pm$ 4.35). On avoiding concentrate source, body weight $(\mathrm{kg})$ was significantly $(\mathrm{p}<0.05)$ higher in R2 group heifers as compared to R1 heifers $(181.98 \pm 3.79 \mathrm{vs} .177 .25 \pm 3.59 \mathrm{~kg})$. ADG of T3 group heifers $(779.9 \pm 23.2 \mathrm{~g} / \mathrm{head} / \mathrm{d})$ was significantly $(\mathrm{p}<0.05)$ higher than T2 and T1 group heifers (723.2 \pm 22.4 vs. $703.9 \pm 21.0)$, respectively. Ignoring concentrate source, ADG ( g/head/d) of R2 group heifers was only numerically higher than that of (R1) heifers $(751.1 \pm 17.9 \mathrm{vs} .720 .2 \pm 18.6)$. Average DMI (kg/head/d) was found statistically similar between T1, T2 and T3 groups ( $4.70 \pm 0.07,4.65 \pm 0.06$ and $4.71 \pm 0.06)$. The observed DMI $(\mathrm{kg} / 100 \mathrm{~kg} \mathrm{BW})$ in T1 group heifers that received $40 \%$ soyaDOC in concentrate was significantly $(p<0.05)$ higher than T2 and T3 group heifers $(2.66 \pm 0.04$ vs. $2.59 \pm 0.03 \& 2.58$ \pm 0.03 ). There was non-significant difference in DMI ( $\mathrm{kg} / \mathrm{kg}$ BW gain) of crossbred heifers fed different concentrate. Ignoring concentrate source, the observed average DMI (kg/head/d) and DMI (kg /100kg BW) in R1 and R2 was (4.57 $\pm 0.05 \& 4.81 \pm 0.05)$ and (2.57 \pm 0.03 \& $2.65 \pm 0.03)$, respectively. DMI $(\mathrm{kg} / \mathrm{head} / \mathrm{d})$ and DMI $(\mathrm{kg} / 100 \mathrm{~kg} \mathrm{BW})$ increased significantly $(\mathrm{p}<0.05)$ when a mixture of wheat straw and groundnut straw was fed to crossbred heifers. There was non-significant difference in DMI ( $\mathrm{kg} / \mathrm{kg}$ BW gain) between R1 and R2 group heifers $(7.33 \pm 0.39 \& 7.05 \pm 0.22)$. The average serum triiodothyronine $(2.69+0.15,2.81+0.16 \& 2.94+0.13 \mathrm{ng} / \mathrm{mL})$ and thyroxine hormone level $(52.20 \pm 2.47,57.86 \pm 4.09 \& 52.30 \pm 2.70)$ of $\mathrm{T} 1, \mathrm{~T} 2$ and $\mathrm{T} 3$ group heifers remained statistically similar. When the concentrate source was ignored, serum triiodothyronine was significantly $(p<0.05)$ higher in R2 group heifers $(2.60 \pm 0.10 v s .3 .02 \pm 0.13$ $\mathrm{ng} / \mathrm{mL})$. The serum thyroxine concentration remained statistically similar on feeding different roughage $(54.30 \pm 2.16 \& 53.94 \pm 2.97$ $\mathrm{ng} / \mathrm{mL}$ ). The results of the study indicate that RDDGS can replace soyaDOC fully in concentrate as a protein source and feeding mixture of groundnut straw and wheat straw is beneficial in terms of growth and do not affect normal body metabolism.

\section{Introduction}

Adequate and balanced feeding of young growing heifer is essential for proper body growth and development of the mammary gland, which can improve the subsequent milk production (Harley and Loor, 2011). In developing nations, majority of livestock is owned by small and marginal farmers and balanced feeding of dairy animals is generally ignored during the non-productive growing phase due to their limited available recourses. The cost of conventional protein sources such as soybean cake and groundnut cake is high and affected by seasonal variation in availability. The scope for increasing area under fodder cultivation is limited hence; using new and alternate feed resources and the best utilization of existing feed resources are primary needs for sustainable animal production. In the last few decades, demand for ethanol is increasing in India as the clean air act amendment (1990), stresses on use of reformulated gasoline to decrease air pollutants (Chatterjee et al., 2016). The Indian government has already made it mandatory to add $10 \%$ ethanol to gasoline. The ethanol requirement will be about 12.7 billion liters by 2030 to achieve E20 (20\% ethanol-blended fuel) target (Shaktivel et al., 2018). Due to limited availability of molasses, molasses alone is not sufficient to meet the growing ethanol needs of the country, especially for use as a biofuel. Hence, a large number of distilleries have started cereal-grain based ethanol production. India is one of the main rice producing country and stands second after China in the world; the rice production was $168.50 \mathrm{MT}$ in 2017 around $21.89 \%$ of total world rice production (Directorate of Economics \& Statistics, 2019). During rice milling, around $9 \%$ of the total weight of paddy rice gets broken (Linscombe, 2006). Rice DDGS (RDDGS) is an important by-product of the distilleries (ethanol production plants) which uses damaged broken/low grade or unfit for human use rice (grains) for fermentation. Nutrients are present in a highly concentrated form (approximately 3 fold) in DDGS (NRC, 1994). RDDGS contains more than $40 \%$ protein and can replace highly prized soybean meal (Yogi et al., 2017; Dey, 2019). The presence of dead yeast cells gives the protein better amino acids composition and very good nutritive value (Pecka-Kiełb et al., 2017). On the other hand, dairy animals are mainly offered cereal straws by farmers as annual availability of straw in India is more than 100 million metric tons for both wheat straw and paddy straw. But cereal straws have low crude protein, low digestibility, less essential mineral and low voluntary intake which is one of the reasons for energy-protein malnutrition among livestock. India is the largest producer of pulses (23.24 MT) and second largest producer of groundnut (9.18 MT) (Directorate of Economics \& 
Statistics, 2019). Cultivation of pulses and legume oilseed like groundnut for humans consumptions yield substantial amount of legume straws. Legume straw contains more $\mathrm{CP}$ than cereal straw and is nutritionally superior. Due to its limited and seasonal availability, its optimal inclusion rate in the cattle diet is important for its efficient utilization. Rice DDGS can be an excellent source of protein and energy, and legume straw can supply more protein than cereal straw for developing replacement heifers.

This study was planned to study the effect of feeding rice DDGS and mixture of legume and non-legume straw on growth, feed intake and thyroid hormone profile of crossbred heifers.

\section{Materials And Methods}

Experimental location, experimental animals and duration: The present work was carried out at Livestock Research Station, College of Veterinary Science and Animal Husbandry, Anand Agricultural University, Anand, Gujarat on twenty-four HFxKankrej (75:25) heifers with an average body weight of $116.13 \pm 4.74 \mathrm{~kg}$ and an average age of $281.92 \pm 13.26$ days (Table 1). Prior permission was taken from CPCSEA through institutional animal ethics committee (IAEC) to perform the experiment (Project: 313/LPM/2019). The experiment started on $24^{\text {th }}$ June 2020 and ended on $9^{\text {th }}$ December 2020, with a total duration of 168 days (a total of 12 fortnights).

Experimental treatments and feeding regime: There were six experimental groups with four animals in each group. Three different concentrates containing 0,20 and 40\% rice DDGS (RDDGS) were offered to T1, T2 and T3 group heifers, respectively. Within each concentrate type, half of the heifers were offered wheat straw (R1 group) and another half a mixture of wheat straw and groundnut straw as dry roughage (R2 group) (Table 2). Concentrate and roughage were given to the experimental heifers in the form of total mixed ration (TMR).

General Management: All the experimental heifers selected for the study were de-wormed with Fenbendazole @ 7.5mg/kg BW before the start of the experiment. They were kept under iso-managerial condition in well ventilated hygienic shed and were provided TMR ration as per treatment schedule. Animals were tied individually with a neck chain in front of the pakka manger with partitions for individual feeding.

Feeding Management: The protein requirements of the heifers under different treatment were met as per ICAR (2013) feeding standard. TMR was offered twice to experimental animals first after tying them at their respective place between 9:00 to 9:30 hours and then between $16: 00$ to $16: 30$ hours. In addition to TMR, heifers were offered fixed $2 \mathrm{~kg} / \mathrm{head} / \mathrm{d}$ and $4 \mathrm{~kg} / \mathrm{head} / \mathrm{d}$ green hybrid napier up to $100 \mathrm{~kg}$ and above $100 \mathrm{~kg} \mathrm{BW}$, respectively and with preset $35 \mathrm{gm} / \mathrm{head} / \mathrm{d}$ mineral mixture throughout the experiment. Protein requirement of experimental heifers were adjusted at biweekly interval as per change in body weight. Feed leftover of individual heifer was weighed on the next day, when no leftover was observed, heifers were offered measured quantity of extra wheat straw so that they could complete their bulk requirement for rumen fill at 17:30 hours.

Analysis of Feeds and Fodder Samples: Representative samples of individual ingredient, concentrate and TMR offered were analyzed for proximate principle as per AOAC (2000). Details are provided in the Table No-4, 5 and 6.

\section{Observations Recorded:}

Body weight: Body weight $(\mathrm{kg})$ of all experimental animals was taken on the day of starting the experiment and thereafter at fortnightly interval by an electronic weighing platform in the morning hours after taking leftover and before watering and feeding.

Feed Intake: A measured quantity of TMR and green fodder were offered to the experimental heifers as per the treatment and leftover was weighed on next day morning between 7:00 to 7.30 hours. Moisture \% of offered TMR, green and leftover feed was measured on biweekly basis so that actual DM consumption can be calculated. Utmost care was taken while feeding animals to get actual feed intake. Mangers were partitioned with bricks and mud keeping sufficient space for individual animals. In general, there was no leftover of green as it was provided in limited quantity.

Hormonal profile: Hormones in experimental heifer's viz. triiodothyronine or $\mathrm{T}_{3}(\mathrm{ng} / \mathrm{ml})$ and thyroxine or $\mathrm{T}_{4}(\mathrm{ng} / \mathrm{ml})$ in serum samples collected at $0,28,56,84,112,140$ and 168 day were analyzed by standard RIA technique using PC-RIA. MAS STRATEC at RIA laboratory, Reproductive Biology Research Unit, AAU, Anand. Triiodothyronine and thyroxine RIA kits were supplied by Immunotech s.r.o., Radiova 1, 10227 Prague 10, Czech Republic.

\section{Analysis of Data}


The experimental data was analyzed at Department of Agricultural Statistics, B. A. College of Agriculture, Anand Agricultural University, Anand (Gujarat) using in house tested software. Design of the experiment was RBD (factorial) and analyzed as per the statistical method described by Snedecor and Cochran (2002).

\section{Results And Discussion}

Body Weight: Average body weight of crossbred heifers recorded at the start and then at fortnightly interval during the experiment is depicted in Fig. 1. Irrespective of concentrate and roughage source, average body weight $(\mathrm{kg})$ at beginning and end of the experiment was $116.13 \pm 4.74$ and $239.47 \pm 5.70$, respectively. The body weight of heifers increased by $106.21 \%(123.34 \mathrm{~kg})$, during the experimental period of 168 days. The average body weight $(\mathrm{kg})$ of crossbred heifers that received $40 \%$ soyaDOC $(T 1), 20 \%$ soyaDOC $+20 \%$ RDDGS (T2) and 40\% RDDGS (T3) in concentrate was found to be $177.54 \pm 4.63,178.99 \pm 4.35$ and $182.32 \pm 4.60$, respectively. The body weight of T3 group heifers was significantly $(\mathrm{p}<0.05)$ higher as compared to T1 and T2 group heifers, while body weight improved numerically in the T2 group as compared to T1 group. When concentrate source was avoided, body weight $(\mathrm{kg})$ was significantly $(p<0.05)$ higher in R2 group heifers that were fed wheat straw and groundnut straw mixture (1:1) as compared to R1 heifers that were offered only wheat straw as dry roughage $(181.98 \pm 3.79 v s .177 .25 \pm 3.59 \mathrm{~kg})$. The interaction between concentrate and roughage source $(\mathrm{T} \times \mathrm{R})$ on body weight was non-significant.

Body weight of heifers increased on replacing soyaDOC with RDDGS in concentrate and in accordance with the findings of Eun et al. (2009) in growing beef steers. They reported that feeding corn-DDGS to beef steer during the growing phase resulted in significant ( $p<$ 0.05 ) improvement in body weight (108 vs. $118 \mathrm{vs} .124 \mathrm{~kg}$ ). Gibb et al. (2008) observed a non-significant but linear increase in body weight ( 557.4 vs. 562.4 vs. $567.7 \mathrm{~kg}$ ) when British cross heifers during the background period received a diet with 0,20 and $40 \%$ of DDGS on diet DM basis. Similarly, Dey (2016) reported numerical improvement in average body weight in crossbred calves $(150.90 \pm 4.56$ vs.159.35 $\pm 7.41 \mathrm{~kg}$ ) on replacing soybean meal with RDDGS. Eun et al. (2009) in finishing beef steer (182 vs. 191 vs. 186), Manthey et al. (2016) in dairy heifers (264.0 vs. 266.2 vs. 266.4 kg), Chandrika (2018) in buffalo calves (293.09 vs. 302.60 vs. 299.44 kg), Beretta et al. (2020) in steers (457.4 vs. 452.6 vs. 460.9 vs. 465 kg) and Huang et al. (2020) in water buffaloes (401 vs. 393 vs. 408 kg) reported nonsignificant change in body weight on feeding DDGS. Contrary to present study, Depenbusch et al. (2009) observed irregular change ( $p \leq$ 0.03) in final body weight ( 483 vs. 494 vs. 483 vs. 474 vs. 473 vs. $458 \mathrm{~kg}$ ) with increasing level of DDGS in the diet. Increase in body weight of crossbred heifers that received a mixture of wheat straw and groundnut straw (R2) was in agreement with the findings of Desai (2020), he observed significant $(p<0.05)$ improvement in body weight, when crossbred calves were offered a mixture of wheat and soybean straw over jowar hay $(127.89 \pm 5.07$ vs. $132.80 \pm 4.60)$. However, only numerical improvement in body weight on feeding mixture of cereal and legume straw over cereal straw feeding was reported by AAU (2019) in crossbred calves $(237.24 \pm 7.80$ vs. $211.34 \pm 6.08$ $\mathrm{kg})$.

\section{Daily Body Weight Gain}

Daily weight gain of crossbred heifers was assessed at fortnightly interval during the experiment. Average daily gain (ADG) worked out at fortnightly interval is depicted in the Fig. 2. ADG (g/head/d) of T3 group heifers that received $40 \%$ RDDGS in concentrate was $779.9 \pm$ 23.2. It was significantly $(\mathrm{p}<0.05)$ higher than $\mathrm{T} 2$ and $\mathrm{T} 1$ group heifers that received $20 \%$ soyaDOC $+20 \%$ RDDGS and $40 \%$ soyaDOC in concentrate, respectively. The ADG ( $\mathrm{g} / \mathrm{head} / \mathrm{d})$ in T1 and T2 group heifers was statistically similar $(723.2 \pm 22.4 \mathrm{vs}$. 703.9 \pm 21.0$)$. Ignoring concentrate source, ADG ( $/ \mathrm{head} / \mathrm{d})$ of heifers that received a mixture of groundnut straw and wheat straw (R2) was numerically higher than that of heifers offered wheat straw (R1) in ration (751.1 \pm 17.9 vs. $720.2 \pm 18.6$ ). The ADG of R2 group heifers was $4.29 \%$ higher than R1 group heifers however, the difference was non-significant. Interaction of concentrate and roughage source $(T \times R)$ on ADG was found to be non-significant.

Improvement in ADG of experimental heifers on replacing full soyaDOC with RDDGS was significant $(p<0.05)$. A similar finding was reported by Eun et al. (2009) on replacing barley grain with corn DDGS in the diet of growing beef steers. They found a significant increase in ADG (kg/d) between control and DDGS fed steers (1.29 vs. 1.40 and 1.47). Likewise, when Dey (2016) replaced 25\% soybean meal in concentrate with $25 \%$ RDDGS, the ADG (g/head/d) in calves improved significantly $(688.9 \pm 29.7 \mathrm{vs}$. 550.7 \pm 16.7$)$. Gibb et al. (2008) in feedlot cattle during background period ( $0.92 \pm 0.06$ vs. $0.92 \pm 0.06$ vs. $0.95 \pm 0.03 \mathrm{~kg} / \mathrm{d})$ as well as in finishing period (1.46 vs. 1.50 vs. 1.57 vs. 1.54 vs. $1.44 \mathrm{~kg} / \mathrm{d}$ ), Eun et al. (2009) in finishing beef steers (1.62 vs. 1.71 vs. $1.66 \mathrm{~kg} / \mathrm{d}$ ), Manthey et al. (2016) in dairy heifers $(0.89 \pm 0.071$ vs. $0.94 \pm 0.083$ vs. $0.97 \pm 0.083 \mathrm{~kg} / \mathrm{d})$, Beretta et al. (2020) in steers (1.50 vs. 1.44 vs. 1.54 vs. 1.62$)$ and Huang et al. (2020) in water buffaloes (1.10 vs. 1.11) reported statistically similar ADG on feedings DDGS in their studies. Numerically higher ADG in experimental heifers that were fed a mixture of groundnut straw and wheat straw (R2) over straw feeding (R1) was parallel with the finding of AAU (2018) in crossbred calves (564.44 vs. $675.56 \mathrm{~g} / \mathrm{head} / \mathrm{d})$. Whereas, significantly $(\mathrm{p}<0.05)$ higher ADG was reported AAU 
(2019) in calves $(869.23 \pm 20.48$ vs. $655.57 \pm 55.57 \mathrm{~g} / \mathrm{head} / \mathrm{d})$ and Desai $(2020)$ in crossbred calves $(522.28 \pm 28.68 \mathrm{vs.} 597.11 \pm 15.84)$ on feeding mixture of cereal and legume straw during their respective experiments.

\section{Feed Intake}

Average dry matter intake (DMI) in experimental heifers assessed at fortnightly interval is depicted in Fig. 3. On avoiding roughage source, average DMI (kg/head/d) of heifers did not change due to feeding RDDGS in T1, T2 and T3 group heifers $(4.70 \pm 0.07,4.65 \pm 0.06$ and $4.71 \pm 0.06)$. Similar finding was reported by Dey (2016) in crossbred calves $(3.90 \pm 0.09 \mathrm{vs} .4 .35 \pm 0.09 \mathrm{~kg} / \mathrm{d})$ as well as in cows (11.1 \pm 0.18 vs. $10.85 \pm 0.55 \mathrm{~kg} / \mathrm{d})$, Ranathunga et al. (2018) in dairy cows ( 25.6 vs. 26.1 vs. 25.1 vs. $25.1 \mathrm{~kg} / \mathrm{d})$, Beretta et al. (2020) in Hereford steers (10.3 vs. 10.6 vs. 10.6 vs. $11.3 \mathrm{~kg} / \mathrm{d})$ ), Huang et al. (2020) in water buffaloes (8.20 vs. 8.35 vs. $8.42 \mathrm{~kg} / \mathrm{d})$ and Fronseca et al. (2021) in Nellore cattle (10.8 vs. 10.7 vs. $10.2 \mathrm{~kg} / \mathrm{d}$ ) on feeding DDGS in their respective feeding trials. Conversely, Gibb et al. (2008) found significant $(\mathrm{p}<0.05)$ and linear increase in $\mathrm{DMI}(\mathrm{kg} / \mathrm{d})$ in feedlot cattle during finishing period $(10.50 \mathrm{vs} .10 .7 \mathrm{vs} .11 .56 \mathrm{vs} .11 .72)$. Eun et al. (2009) observed significant decrease in DMI on feeding corn-DDGS during background period (8.48 vs. 7.83 and $7.56 \mathrm{~kg} / \mathrm{d})$ and finishing period (11.3 vs. 10.5 and $10.4 \mathrm{~kg} / \mathrm{d}$ ) in beef steers. Likewise, Garnsworthy et al. (2020) in dairy cows found linear decrease in DMI $(23.1,23.1,22.9$ and $22.3 \mathrm{~kg} / \mathrm{d}$ ) with significant decrease at $240 \mathrm{~g} / \mathrm{kg}$ WDDGS level. Depenbusch et al. (2009) found irregular pattern $(p<0.03)$ in DMI with maximum DMI at 15\% DGS diet. The DMI was stimulated when DDGS was incorporated up to $20 \%$ of the DM in dairy cow diet. At higher inclusion, decrease in feed intake might be caused by high fat concentration (Council, U. S. 2012). Feeding mixture of wheat straw and groundnut straw significantly $(p<0.05)$ improved DMI $(\mathrm{kg} / \mathrm{head} / \mathrm{d})$ in heifers $(4.57 \pm 0.05 \mathrm{vs} .4 .81 \pm 0.05)$. Parallel finding was reported by Desai $(2020)$ in crossbred calves $(3.62+0.11 \mathrm{vs} .3 .47+0.13 \mathrm{~kg} / \mathrm{d})$. AAU (2018) in crossbred calves $(5.28$ vs. $4.97 \mathrm{~kg} / \mathrm{d})$ and AAU (2019) in calves $(5.82 \pm 0.20$ vs. $5.65 \pm 0.13 \mathrm{~kg} / \mathrm{d})$ reported non- significant change in DMI. However, there was numerical increase in DMI $(\mathrm{kg} / \mathrm{d})$ when mixture of cereal and legume straw was fed over cereal straw. The interaction between concentrate and roughage source on DMI $(\mathrm{kg} / \mathrm{head} / \mathrm{d})$ was also found to be significant $(\mathrm{p}<0.05)$. Highest DMI $(\mathrm{kg} / \mathrm{head} / \mathrm{d})$ was found in T1R2 group heifers $(4.96 \pm 0.08)$ that received $40 \%$ soybean meal in concentrate and a mixture of $50 \%$ wheat straw and $50 \%$ groundnut straw whereas, lowest in T1R1 group heifers $(4.45 \pm 0.10)$ that received $40 \%$ soybean meal in concentrate and only wheat straw as dry roughage.

DMI (kg/100kg BW) was also calculated at fortnightly interval (Fig. 4) it reduced significantly $(\mathrm{P}<0.05)$ when soyaDOC was replaced with RDDGS ( $2.66 \pm 0.04$ vs. $2.59 \pm 0.03$ and $2.58 \pm 0.03)$. The result was in partial accordance with findings of Dey (2016) who reported numerical decrease in DMI ( $\mathrm{kg} / 100 \mathrm{~kg} \mathrm{BW}$ ) of cows fed concentrate containing 25\% RDDGS (3.26 vs. 3.38). On the other hand, Chandrika (2018) in buffalo calves (2.15 vs. 2.18 vs. 2.16) and Beretta et al. (2020) in steers (2.72 vs. 2.75 vs. 2.75 vs. 2.75) found non-significant change in DMI (kg /100kg BW) when DDGS was included to the diet. Heifers that received a mixture of $50 \%$ wheat straw and $50 \%$ groundnut straw consumed significantly higher DM $(2.57 \pm 0.03$ vs. $2.65 \pm 0.03 \mathrm{~kg} / 100 \mathrm{~kg} \mathrm{BW})$. This finding was in partial agreement with the finding of Desai $(2020)$ in crossbred calves $(2.76+0.03$ vs. $2.75+0.04)$, all of them found numerical increase in DMI $(\mathrm{kg} / 100 \mathrm{~kg} \mathrm{BW})$ on feeding mixture of cereal and legume straw to experimental animals. Interaction between concentrate and roughage source on DMI ( $\mathrm{kg} / 100 \mathrm{~kg} \mathrm{BW})$ was also found significant $(\mathrm{p}<0.05)$. Highest DMI $(\mathrm{kg} / 100 \mathrm{~kg} \mathrm{BW})$ was found in T1R2 $(2.75 \pm 0.06)$ and the lowest in T1R1 and T3R1 (2.56 \pm 0.05$)$ groups.

Fortnightly DMI (kg/kg BW gain) of experimental heifers is presented in Fig. 5. The average DMI (kg/kg BW gain) of crossbred heifers that received $40 \%$ soyaDOC (T1), $20 \%$ soyaDOC $+20 \%$ RDDGS (T2) and $40 \%$ RDDGS (T3) in concentrate was $7.65 \pm 0.53,7.17 \pm 0.29$ and $6.75 \pm 0.30$, respectively. There was non-significant differen ce in DMI ( $\mathrm{kg} / \mathrm{kg} \mathrm{BW}$ gain) of crossbred heifers fed different concentrate. However, replacement of soyaDOC resulted in linear decrease in DMI $(\mathrm{kg} / \mathrm{kg}$ BW gain). When concentrate source was ignored, average DMI (kg/kg BW gain) of crossbred heifers of R1 and R2 group was found to be $7.33 \pm 0.39$ and $7.05 \pm 0.22$, respectively. There was nonsignificant difference in DMI ( $\mathrm{kg} / \mathrm{kg}$ BW gain). The interaction between concentrate and roughage source $(T \times R)$ on DMI $(\mathrm{kg} / \mathrm{kg} B W \mathrm{gain})$ was found to be non-significant. Gibb et al. (2008) in British cross heifers $(0.134 \pm 0.007$ vs. $0.135 \pm 0.007 v s .0 .137 \pm 0.004)$ during background period and Eun et al. (2009) in finishing beef steers ( $0.146 \mathrm{vs} .0 .165 \mathrm{vs}$. 0.162$)$ also reported similar gain to feed ratio on feeding DDGS in their studies. Gibb et al. (2008) in finishing period reported linear and significant $(p<0.05)$ decrease in gain to feed ration with increase in DDGS in diet of heifers $(0.140$ vs. 0.140 vs. 0.137 vs. 0.132 vs. 0.127$)$. While, Eun et al. (2009) found that gain to feed ratio increased linearly and significantly $(p<0.05)$ with increases in DDGS in diet of steers during growing phase $(0.152 \mathrm{vs} .0 .179 \mathrm{vs}$. 0.195). The DMI (kg/kg BW gain) did not differ statistically when mixture of wheat straw and groundnut straw (R2) was offered to heifer against wheat straw (R1). Though, there was numerical decrease in DMI (kg/kg BW gain) in R2 group heifers. Similar finding was reported by Desai $(2020)$ in crossbred calves. He found significant $(p<0.05)$ decrease in DMI $(\mathrm{kg} / \mathrm{kg}$ BW gain), when mixture of cereal and legume straw was offered to crossbred calves $(6.93+0.31$ vs. $9.13+0.69)$.

\section{Thyroid Hormone Profile}

Page 5/12 
Average serum triiodothyronine $(\mathrm{ng} / \mathrm{mL})$ of experimental at different days of the experimental period is depicted in Fig. 6. Overall serum triiodothyronine $(\mathrm{ng} / \mathrm{mL})$ in heifers, irrespective of treatments and periods was found to be $2.81 \pm 0.08$. When roughage source was ignored, average serum triiodothyronine $(\mathrm{ng} / \mathrm{mL})$ in T1, T2 and T3 group heifers was observed to be $2.69 \pm 0.15,2.81 \pm 0.16$ and $2.94 \pm$ 0.13 , respectively. The serum triiodothyronine $(\mathrm{ng} / \mathrm{mL}$ ) was statistically similar among $\mathrm{T} 1, \mathrm{~T} 2$ and $\mathrm{T} 3$ group heifers. When the concentrate source was ignored, triiodothyronine $(\mathrm{ng} / \mathrm{mL})$ in R1 and R2 group heifers was found to be $2.60 \pm 0.10$ and $3.02 \pm 0.13$, respectively. Feeding different roughage source resulted in a significant increase serum triiodothyronine concentration. The serum triiodothyronine $(\mathrm{ng} / \mathrm{mL})$ was significantly $(\mathrm{p}<0.05)$ higher in R2 group heifers. The interaction between concentrate and roughage source $(T \times R)$ was found to be significant on triiodothyronine level. The serum triiodothyronine $(\mathrm{ng} / \mathrm{mL})$ was highest in T3R2 (3.39 \pm 0.17$)$ and lowest in T1R1 $(2.22 \pm 0.15)$ group heifers. The observed serum average triiodothyronine $(\mathrm{ng} / \mathrm{mL})$ in heifers was higher than reported by Periara et al. (2008) in different cattle breeds $(2.30 \pm 0.07$ vs. $1.63 \pm 0.07$ vs. $1.50 \pm 0.10$ vs. $2.02 \pm 0.07 \mathrm{ng} / \mathrm{ml})$. Pandey (2015) in Tharparker (1.79 \pm 0.04$)$ as well as in Karanfries (1.79 \pm 0.03$)$ and Baek et al. (2019) in Hanwoo steers (2.24). Conversely, Paulikova et al. (2011) reported higher triiodothyronine level in heifers $(3.92 \mathrm{ng} / \mathrm{mL})$ than present study. However, they found lower serum triiodothyronine $(\mathrm{ng} / \mathrm{mL})$ in dairy cows (2.28) and calves (1.91).

Average serum thyroxine concentration in heifers at different days during the experimental period is depicted in Fig. 7.The overall average serum thyroxine $(\mathrm{ng} / \mathrm{mL})$ in crossbred heifers, irrespective of treatments and periods was found to be 54.12 . Average serum thyroxine $(\mathrm{ng} / \mathrm{mL}$ ) in heifers that received $40 \%$ soyaDOC (T1), $20 \%$ soyaDOC $+20 \%$ RDDGS (T2) and $40 \%$ RDDGS (T3) in concentrate was found to be $52.20 \pm 2.47,57.86 \pm 4.09$ and $52.30 \pm 2.70$, respectively. The serum thyroxine concentration of $T 1, T 2$ and $T 3$ group heifers remained statistically similar. On ignoring concentrate source, average serum thyroxine concentration in R1 and R2 group heifers was found to be $54.30 \pm 2.16$ and $53.94 \pm 2.97$, respectively. The serum thyroxine concentration also remained statistically similar on feeding different roughage. The interaction of concentrate and roughage source on serum thyroxine level was found to be significant. The heifers of the T2R1 group had the highest $(62.29 \pm 2.41 \mathrm{ng} / \mathrm{mL})$ and T3R1 had the lowest thyroxine level $(47.73 \pm 3.97 \mathrm{ng} / \mathrm{mL})$. Average serum thyroxin level in heifers was within the reference range depicted in Clinical Biochemistry of Domestic Animals by Kaneko et al. (2008) in cows $(41.58-85.24 \mathrm{ng} / \mathrm{mL})$. Conversely, Periara et al. (2008) in different cattle breeds $(82.6 \pm 3.8,65.5 \pm 3.8,69 \pm 4.0$ and $69 \pm 4.0)$, Paulikova et al. (2011) in heifers (95) and Pandey (2015) in Tharparker (65.03 \pm 0.34$)$ as well as in Karanfries (64.32 \pm 0.35$)$ observed higher thyroxin concentration $(\mathrm{ng} / \mathrm{mL})$ in their respective studies.

\section{Conclusions}

Body weight and daily gain in heifers improved significantly when full soyaDOC in concentrate was completely replaced by RDDGS in concentrate. Feeding a mixture of groundnut straw and wheat straw in 1:1 also improved body weight significantly in heifers. DMI increased significantly on feeding mixture of wheat straw and groundnut straw over only wheat straw feeding. Serum triiodothyronine and thyroxine hormone levels of heifers were normal on feeding rice DDGS and groundnut straw. So it can be concluded that RDDGS can replace soyaDOC fully in concentrate as a protein source and feeding mixture of groundnut straw and wheat straw is beneficial in terms of growth and do not affect normal body metabolism.

\section{Declarations}

Conflict of interest: The authors declare no conflict of interest related to this study and approve their consent for publication.

Availability of data and material: The submitted manuscript is part of PhD thesis work of first author.

Ethics approval: CPCSEA Registration No. 486/GO/Re-S/ReBi-L/01/CPCSEA. Prior permission was taken from CPCSEA through institutional animal ethics committee (IAEC) to perform the experiment (Project: 313/LPM/2019).

Code availability: The experimental data was analyzed at Department of Agricultural Statistics, B. A. College of Agriculture, Anand Agricultural University, Anand (Gujarat) using in house tested software. Design of the experiment was factorial (RBD) and analyzed as per the statistical method described by Snedecor and Cochran (2002). 
Funding: Authors are thankful to Director Research, AAU, Anand and Dean CVSc \& AH, Anand for providing necessary aid and financial support to carry out the study. $1^{\text {st }}$ author is also a recipient of ICAR-JRF/SRF (F.No. EDN/1/25/2015) fellowship hence acknowledges the ICAR, India.

Contributions: All the authors contributed to the research, experiment and in manuscript preparation. S.V. Shah, Manish Pandey, D. C. Patel, K. N. Wadhwani and P. R. Pandya were responsible for the design and the preparation for the experiment. The experiment and related discussion were performed by Manish Pandey, S.V. Shah, D. C. Patel, P. R. Pandya, K. N. Wadhwani and N. P. Sarvaiya. Manish Pandey and S.V. Shah wrote the manuscript. All the authors read and approved the final manuscript.

\section{References}

1. Anand Agricultural University. Proceeding of 14th Meeting of Agricultural Research Subcommittee Animal Production and Fisheries subcommittee. AAU, Anand, Gujarat, India. Annual Progress Report, 2018.

2. Anand Agricultural University. Proceeding of 15th Meeting of Agricultural Research Subcommittee Animal Production and Fisheries subcommittee. AAU, Anand, Gujarat, India. Annual Progress Report, 2019

3. Association of Analytical Chemist. Official methods of analysis (17th ed). Washington, D.C.U.S.A. 2000.

4. Baek, Y. C., Kim, M., Jeong, J. Y., Oh, Y. K., Lee, S. D., Lee, Y. K., Ji, S. Y., \& Choi, H. Effects of short-term acute heat stress on physiological responses and heat shock proteins of Hanwoo steer (Korean cattle). Journal of Animal Reproduction and Biotechnology, 2019, 34(3), 173-182.

5. Beretta, V., Simeone, A., Franco, J., Bentancur, O., Novac, M., Panizza, V., Rodríguez, M. V. Using sorghum dry distillers' grains plus solubles in sorghum-based finishing diets: feed utilization, cattle performance and carcass traits. Animal Feed Science and Technology, 2020, 271, 114731.

6. Chandrika, R. N. Rice dried distillers grains with soluble as an alternate protein source in the diet of calves. (M.V.Sc. thesis, Guru Angad Dev Veterinary and Animal Sciences University, Ludhiana). 2018. Retrieved from https://krishikosh.egranth.ac.in.

7. Chatterjee, A., Dey, D., Mandal, D. K., Mohammad, A. \& Bhakat, C. Utilization of Rice Dried Distillery Grain with Soluble as Feed for Ruminants. International Conference on Agriculture, Food Science, Natural Resource Management and Environmental Dynamics, 2016, 74-77.

8. Council, U. G. A guide to distiller's dried grains with soluble (3rd ed.). U. S. Grain Council. 2012. http://www.ddgs.umn.edu/prod/groups/cfans/@pub/@cfans/@ ansci/documents/ass et/cfans_asset_417244.Pdf.

9. Depenbusch, B. E., Coleman, C. M., Higgins, J. J., \& Drouillard, J. S. Effects of increasing levels of dried corn distillers grains with solubles on growth performance, carcass characteristics, and meat quality of yearling heifers. Journal of Animal Science, 2009, 87(8), 2653-2663.

10. Desai, Y. A. Effect of watering frequency and feed on growth of crossbred calves. (M.V.Sc. thesis, College of Veterinary Science and Animal Husbandry, Anand Agricultural University, Anand, Gujarat). 2020.

11. Dey, D. Effect of feeding rice distillers grain with soluble on growth rate and milk production of crossbred cattle. (M.V.Sc. thesis, ICARNational Dairy Research Institute, Deemed University Karnal, Haryana, India). 2016. Retrieved from https://krishikosh.egranth.ac.in.

12. Dey, D., Sharma, B., Mohammad, A., Mandal, D. K., Bhakat, C., Dutta, T. K., Chatterjee, A.. Effect of feeding rice distillers dried grain with solubles as major protein source on nutrient digestibility and growth performance of Jersey crossbred calves. Indian Journal of Animal Research, 2019, 54(4), 446-451.

13. Directorate of Economics \& Statistics. Pocket Book of Agricultural Statistics- 2019. Ministry of Agriculture \& Farmers Welfare, Department of Agriculture, Cooperation \& Farmers Welfare, Directorate of Economics \& Statistics, GOI, New Delhi. 2019

14. Eun, J. S., ZoBell, D. R., \& Wiedmeier, R. D. Influence of replacing barley grain with corn-based dried distillers grains with solubles on production and carcass characteristics of growing and finishing beef steers. Animal Feed Science and Technology, 2009, 152(1-2), 72-80.

15. Fonseca, N. V. B., Cardoso, A. D. S., Hoffmann, A., Leite, R. G., Ferrari, A. C., Fernandes, M. H. M. D. R., \& Reis, R. A.. Characterization and effects of DDG on the intake and digestibility of finishing bulls in feedlots. Acta Scientiarum Animal Sciences, $2021,43$. 
16. Garnsworthy, P. C., Marsden, M., Goodman, J. R., Saunders, N. Inclusion of wheat dried distillers' grains with solubles from bioethanol plants in diets for dairy cows. Animals, 2021, 11(1), 70.

17. Gibb, D. J., Hao, X., McAllister, T. A. Effect of dried distillers' grains from wheat on diet digestibility and performance of feedlot cattle. Canadian Journal of Animal Science, 2008, 88(4), 659-665.

18. Huang, J., Wu, T., Sun, X., Zou, C., Yang, Y., Cao, Y., Yang, Y., Iqbal, M. W., Lin, B.. Effect of replacing conventional feeds with tropical agricultural by-products on the growth performance, nutrient digestibility and ruminal microbiota of water buffaloes. Journal of animal physiology and animal nutrition, 2020, 104(4), 1034-1042.

19. Hurley, W. L., Loor, J. J. Mammary gland: growth, development and involution. In Encyclopedia of Dairy Sciences: Second Edition. 2011.

20. Indian Council of Agricultural Research.. Nutrients Requirements of Cattle and Buffalo. Official Publication. Nutrients requirement of Animals. ICAR, New Delhi, India. 2013.

21. Kaneko, J. J., Harvey, J. W., Bruss, M. L. (Eds.).. Clinical biochemistry of domestic animals. Academic press. 2008.

22. Linscombe, S.. Rice Quality Determines Payment. 2006. Available online at: https://www.Isuagcenter.com/portals/our_offices/research_stations/rice/features/publications/rice-quality-determines-payment.

23. Manthey, A. K., Anderson, J. L., Perry, G.A.. Feeding distillers dried grains in replacement of forage in limit-fed dairy heifer rations: Effects on growth performance, rumen fermentation, and total-tract digestibility of nutrients. Journal of dairy science, 2016, 99(9), $7206-7215$.

24. National Research Council. Nutrient Requirements of Poultry. National Academy of ingredient of poultry diets, World's Science. Washington, D.C. 1994.

25. Pandey, P. Effect of elevated temperature and carbon-dioxide level on physiological and biochemical functions in zebu and crossbred cattle. (M.V.Sc. thesis, ICAR-National Dairy Research Institute, Karnal, India). Retrieved from https://krishikosh.egranth.ac.in. 2015.

26. Paulíková, I., Seidel, H., Nagy, O., Tóthová, V., Kováč, G. Concentrations of thyroid hormones in various age categories of ruminants and swine. Acta veterinaria, 2011, 61(5-6), 489-503.

27. Pecka-Kiełb, E., Zachwieja, A., Miśta, D., Zawadzki, W., Zielak-Steciwko, A. Use of Corn Dried Distillers Grains (DDGS) in Feeding of Ruminants. In Frontiers in Bioenergy and Biofuels. IntechOpen. 2017.

28. Pereira, A. M., Baccari, F., Titto, E. A., Almeida, J. A. Effect of thermal stress on physiological parameters, feed intake and plasma thyroid hormones concentration in Alentejana, Mertolenga, Frisian and Limousine cattle breeds. International journal of biometeorology, 2008, 52(3), 199-208.

29. Ranathunga, S. D., Kalscheur, K. F., Anderson, J. L., Herrick, K. J. Production of dairy cows fed distillers dried grains with solubles in low-and high-forage diets. Journal of dairy science, 2018, 101(12), 10886-10898.

30. Sakthivel, P., Subramanian, K. A., Mathai, R. Indian scenario of ethanol fuel and its utilization in automotive transportation sector. Resources, Conservation and Recycling, 2018, 132, 102-120.

31. Yogi, R. K., Thakur, S. S., Mohini, M., Singh, S. K., Malik, T. In vitro evaluation of concentrate mixtures containing incremental level of rice dried distillers grain with solubles replacing oil cakes in concentrate mixture. Indian Journal of Animal Nutrition, 2017, 34 (2), $163-168$.

\section{Tables}

Table 1 Details of experimental animals

\begin{tabular}{|c|c|c|c|c|}
\hline \multirow{2}{*}{\multicolumn{2}{|c|}{ (Groups) }} & \multirow{3}{*}{$\begin{array}{c}\text { Number of heifers } \\
4\end{array}$} & \multicolumn{2}{|c|}{ Traits at the start of Experiment } \\
\hline & & & Body Weight (kg) & Age (days) \\
\hline \multirow[t]{2}{*}{ T1 } & R1 & & $115.85 \pm 15.55$ & $247.75 \pm 46.26$ \\
\hline & R2 & 4 & $116.35 \pm 12.50$ & $286.25 \pm 16.10$ \\
\hline \multirow[t]{2}{*}{ T2 } & R1 & 4 & $116.00 \pm 12.29$ & $257.75 \pm 32.30$ \\
\hline & $\mathbf{R} 2$ & 4 & $116.55 \pm 12.07$ & $315.00 \pm 22.81$ \\
\hline \multirow[t]{2}{*}{ T3 } & R1 & 4 & $116.00 \pm 12.53$ & $289.50 \pm 47.19$ \\
\hline & $\overline{\mathrm{R} 2}$ & 4 & & $295.25 \pm 29.47$ \\
\hline \multicolumn{2}{|c|}{ Total } & 24 & $116.13 \pm 4.74$ & $281.92 \pm 13.26$ \\
\hline \multicolumn{3}{|c|}{ Average $\pm \mathrm{SE}$} & & \\
\hline
\end{tabular}


Table 2: Concentrate type and dry roughage offered to experimental heifers

\begin{tabular}{|c|c|c|c|c|c|}
\hline \multirow{3}{*}{\multicolumn{2}{|c|}{ (Groups) }} & \multirow{3}{*}{$\begin{array}{l}\text { Number } \\
\text { of heifers }\end{array}$} & \multicolumn{3}{|c|}{ Ingredients in Total Mixed Ration } \\
\hline & & & \multirow{2}{*}{ Concentrate type } & \multicolumn{2}{|c|}{ Dry Roughage } \\
\hline & & & & Wheat Straw & Groundnut straw \\
\hline \multirow[t]{2}{*}{ T1 } & $\overline{\mathrm{R} 1}$ & 4 & \multirow{2}{*}{ Concentrate -I $\quad 50 \%$} & $50 \%$ & $0 \%$ \\
\hline & R2 & 4 & & $25 \%$ & $25 \%$ \\
\hline \multirow[t]{2}{*}{ T2 } & R1 & 4 & \multirow[t]{2}{*}{ Concentrate -II 50\% } & $50 \%$ & $0 \%$ \\
\hline & $\overline{\mathrm{R} 2}$ & 4 & & $25 \%$ & $25 \%$ \\
\hline \multirow[t]{2}{*}{ T3 } & R1 & 4 & \multirow[t]{2}{*}{ Concentrate -III 50\% } & $50 \%$ & $0 \%$ \\
\hline & $\overline{\mathrm{R} 2}$ & 4 & & $25 \%$ & $25 \%$ \\
\hline
\end{tabular}

Table 3: Different concentrate mixtures and their composition

\begin{tabular}{|c|c|c|c|}
\hline \multirow{2}{*}{ Particulars } & \multicolumn{3}{|c|}{ Ingredients (\%) } \\
\cline { 2 - 4 } & Amul Dan & SoyaDOC & RDDGS \\
\hline Concentrate -I & 60 & 40 & 0 \\
\hline Concentrate -II & 60 & 20 & 20 \\
\hline Concentrate -III & 60 & 0 & 40 \\
\hline
\end{tabular}

*Amul Dan is conventional concentrate sold by Anand Milk Union Limited, Anand (Gujarat) and soyaDOC - soybean de-oiled cake

Table 4: Proximate composition of various feed ingredients used in the experiment, \% DM basis

\begin{tabular}{|l|c|c|c|c|c|c|}
\hline Particulars & Rice DDGS & SoyaDOC & Amul Dan & Groundnut Straw & Wheat Straw & Hybrid Napier \\
\hline OM & 95.18 & 87.60 & 86.27 & 90.79 & 87.54 & 80.14 \\
\hline CP & 44.67 & 43.15 & 18.8 & 10.67 & 2.63 & 10.60 \\
\hline EE & 7.27 & 0.15 & 2.79 & 2.24 & 3.33 & 2.32 \\
\hline CF & 2.04 & 8.93 & 16.26 & 30.37 & 39.26 & 28.18 \\
\hline Ash & 4.82 & 12.45 & 13.73 & 9.21 & 12.46 & 19.87 \\
\hline NFE & 41.2 & 35.32 & 48.42 & 47.51 & 42.32 & 39.03 \\
\hline
\end{tabular}

*OM -organic matter, CP-Crude protein, EE -Ether extract, CF- Crude fiber, NFE- Nitrogen Free Extract. Analysis was performed at ANRS,AAU, Anand

Table 5: Proximate composition of concentrate mixture with RDDGS, \% DM basis

\begin{tabular}{|c|c|c|c|}
\hline Particulars & $\begin{array}{c}\text { Concentrate -I } \\
\text { (0\% RDDGS) }\end{array}$ & $\begin{array}{c}\text { Concentrate-II } \\
\text { (20\% RDDGS) }\end{array}$ & $\begin{array}{c}\text { Concentrate -III } \\
\text { (40\% RDDGS) }\end{array}$ \\
\hline OM & 86.58 & 88.18 & 89.77 \\
\hline CP & 28.33 & 28.91 & 29.17 \\
\hline EE & 1.70 & 3.05 & 4.42 \\
\hline CF & 12.66 & 11.36 & 10.48 \\
\hline Ash & 13.42 & 11.82 & 10.23 \\
\hline NFE & 43.89 & 44.86 & 45.70 \\
\hline
\end{tabular}

Table 6: Proximate composition of different TMR offered to heifers, \% DM basis 


\begin{tabular}{|c|c|c|c|c|c|c|}
\hline Particulars & TMR-1 & TMR-2 & TMR-3 & TMR-4 & TMR-5 & TMR-6 \\
\hline OM & 86.94 & 88.38 & 87.73 & 88.76 & 88.58 & 89.38 \\
\hline CP & 15.46 & 17.35 & 15.68 & 17.72 & 15.86 & 17.85 \\
\hline EE & 2.52 & 2.18 & 3.23 & 2.86 & 3.71 & 3.54 \\
\hline CF & 25.90 & 23.48 & 24.86 & 22.43 & 24.68 & 22.36 \\
\hline Ash & 13.06 & 11.69 & 12.27 & 11.24 & 11.42 & 10.62 \\
\hline NFE & 43.06 & 45.30 & 43.96 & 45.75 & 44.33 & \multirow{2}{*}{} \\
& & & & & & 1. \\
\hline
\end{tabular}

Table 7: Body weight, ADG, DMI and Thyroid Hormone profile of experimental heifers

\begin{tabular}{|c|c|c|c|c|c|c|c|c|}
\hline \multirow[t]{3}{*}{ Particulars } & \multicolumn{6}{|c|}{ Group } & \multirow{3}{*}{ R1 } & \multirow{3}{*}{ R2 } \\
\hline & \multicolumn{2}{|c|}{ T1 } & \multicolumn{2}{|c|}{ T2 } & \multicolumn{2}{|c|}{ T3 } & & \\
\hline & R1 & $\mathrm{R} 2$ & R1 & R2 & R1 & R2 & & \\
\hline \multirow[t]{2}{*}{$\begin{array}{l}\text { Body Weight } \\
\text { (kg) }\end{array}$} & $\begin{array}{l}174.52 \\
\pm 6.71 \\
\end{array}$ & $\begin{array}{l}180.55 \\
\pm 6.42 \\
\end{array}$ & $176.86 \pm 5.72$ & $181.12 \pm 6.59$ & $\begin{array}{l}180.36 \\
\pm 6.27 \\
\end{array}$ & $\begin{array}{c}184.28 \\
\pm 6.77 \\
\end{array}$ & \multirow[t]{2}{*}{$177.25^{\mathrm{a}} \pm 3.59$} & \multirow{2}{*}{$\begin{array}{c}181.98^{b} \\
\pm 3.79\end{array}$} \\
\hline & \multicolumn{2}{|c|}{$177.54^{\mathrm{A}} \pm 4.63$} & \multicolumn{2}{|c|}{$178.99^{\mathrm{A}} \pm 4.35$} & \multicolumn{2}{|c|}{$182.32^{\mathrm{B}} \pm 4.60$} & & \\
\hline CD & & & & 2.807 & & & \multicolumn{2}{|c|}{2.292} \\
\hline \multirow[t]{3}{*}{ ADG (g/head/d) } & $\begin{array}{l}679.1 \\
+31.4\end{array}$ & $\begin{array}{l}728.6 \\
+277\end{array}$ & $\begin{array}{r}711.5 \\
+319\end{array}$ & $\begin{array}{r}735.0 \\
+316\end{array}$ & $\begin{array}{l}770.0 \\
+326\end{array}$ & $\begin{array}{l}789.9 \\
+334\end{array}$ & \multirow{3}{*}{$\begin{array}{l}720.2 \\
\pm 18.6\end{array}$} & 751.1 \\
\hline & \pm 31.4 & \pm 27.7 & \multirow{3}{*}{\multicolumn{2}{|c|}{$\begin{array}{c}723.2^{\mathrm{A}} \pm 22.4 \\
52.56\end{array}$}} & \pm 32.6 & \pm 33.4 & & \pm 17.9 \\
\hline & \multicolumn{2}{|c|}{$703.9^{\mathrm{A}} \pm 21.0$} & & & \multirow{2}{*}{\multicolumn{2}{|c|}{$779^{\mathrm{B}} .9 \pm 23.2$}} & & \\
\hline CD & & & & & & & \multicolumn{2}{|l|}{ NS } \\
\hline \multirow[t]{2}{*}{ DMI (kg/head/d) } & $\begin{aligned} & 4.45 \\
&+0.10\end{aligned}$ & $\begin{array}{c}4.96 \\
+0.08\end{array}$ & $\begin{array}{l}4.60 \\
+0.08\end{array}$ & $\begin{array}{c}4.70 \\
+0.09\end{array}$ & & $\begin{array}{c}4.78 \\
+0.09\end{array}$ & \multirow{2}{*}{$\begin{array}{l}4.57^{a} \\
\pm 0.05\end{array}$} & $4.81^{b}$ \\
\hline & \multicolumn{2}{|c|}{$4.70 \pm 0.07$} & \multicolumn{2}{|c|}{$4.65 \pm 0.06$} & \multicolumn{2}{|c|}{$4.71 \pm 0.06$} & & \pm 0.05 \\
\hline CD & & & & NS & & & \multicolumn{2}{|c|}{0.055} \\
\hline \multirow[t]{2}{*}{ DMI (kg/100kgBW) } & $\begin{array}{r}2.56 \\
+0.05\end{array}$ & $\begin{array}{r}2.75 \\
+0.06\end{array}$ & $\begin{array}{c}2.58 \\
+0.04\end{array}$ & $\begin{array}{l}2.60 \\
+0.05\end{array}$ & & $\begin{array}{r}2.60 \\
+0.05\end{array}$ & \multirow{2}{*}{$\begin{array}{l}2.57^{\mathrm{a}} \\
\pm 0.03\end{array}$} & $2.65^{\mathrm{b}}$ \\
\hline & \multicolumn{2}{|c|}{$2.66^{\mathrm{B}} \pm 0.04$} & \multicolumn{2}{|c|}{$2.59^{\mathrm{A}} \pm 0.03$} & \multicolumn{2}{|c|}{$2.58^{\mathrm{A}} \pm 0.03$} & & \\
\hline CD & & & & .035 & & & \multicolumn{2}{|c|}{0.029} \\
\hline $\begin{array}{c}\text { DMI (kg/kg BW } \\
\text { gain) }\end{array}$ & $\begin{aligned} & 7.96 \\
\pm & 1.01\end{aligned}$ & $\begin{array}{c}7.35 \\
\pm 0.35\end{array}$ & $\begin{array}{c}7.28 \\
\pm 0.44\end{array}$ & $\begin{array}{c}7.06 \\
\pm 0.39\end{array}$ & & $\begin{array}{c}6.74 \\
\pm 0.42\end{array}$ & $\begin{array}{c}7.33 \\
\pm 0.39\end{array}$ & $\begin{array}{c}7.05 \\
\pm 0.22\end{array}$ \\
\hline & 7.65 & 0.53 & & $7 \pm 0.29$ & & $5 \pm 0.30$ & & \\
\hline CD & & & & NS & & & NS & \\
\hline $\mathrm{T}_{3}(\mathrm{ng} / \mathrm{mL})$ & $\begin{array}{l}2.22 \\
+0.15\end{array}$ & $\begin{array}{l}3.15 \\
+024\end{array}$ & $\begin{array}{l}3.09 \\
+020\end{array}$ & $\begin{array}{c}2.53 \\
+023\end{array}$ & 2.4 & $\begin{array}{c}3.39 \\
+017\end{array}$ & $2.60^{\mathrm{a}}$ & $3.02^{b}$ \\
\hline & $\frac{ \pm 0.15}{2.69}$ & $\begin{array}{l} \pm U .24 \\
=0.15\end{array}$ & $\begin{array}{l} \pm 0.20 \\
2.8\end{array}$ & $\begin{array}{c} \pm 0.23 \\
\pm 0.16\end{array}$ & & $\begin{array}{l}\mid \pm 0.1 / \\
\pm 0.13\end{array}$ & \pm 0.10 & \pm 0.13 \\
\hline CD & & & & NS & & & 0.25 & \\
\hline $\mathrm{T}_{4}(\mathrm{ng} / \mathrm{mL})$ & 52.90 & 51.51 & $62.29 \pm 2.41$ & 53.43 & & 56.87 & 54.30 & 57.86 \\
\hline & \pm 4.19 & \pm 2.70 & & $\begin{array}{r} \pm .81 \\
\end{array}$ & & \pm 3.52 & \pm 2.16 & \pm 4.09 \\
\hline & & & & $20 \pm 2.47$ & & & & \\
\hline CD & & & & NS & & & NS & \\
\hline
\end{tabular}

Means with different superscripts in a row (A, B) differ significantly for concentrate and $(a, b)$ differ significantly for roughage source ( $<<0.05$ ). *CD- Critical Difference at 5\% significance level.

\section{Figures}

Figure 1

Average fortnightly body weight $(\mathrm{kg})$ of crossbred heifers 


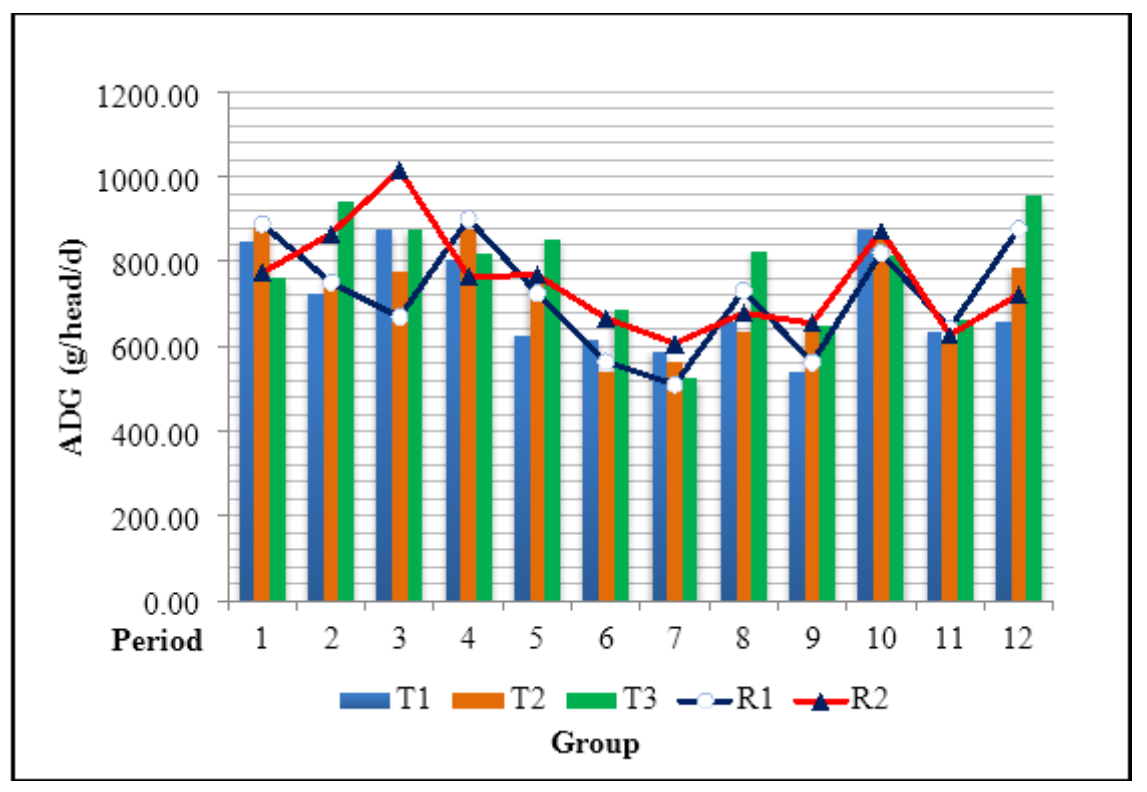

Figure 2

Average fortnightly ADG ( $\mathrm{g} / \mathrm{head} / \mathrm{d})$ of crossbred heifer

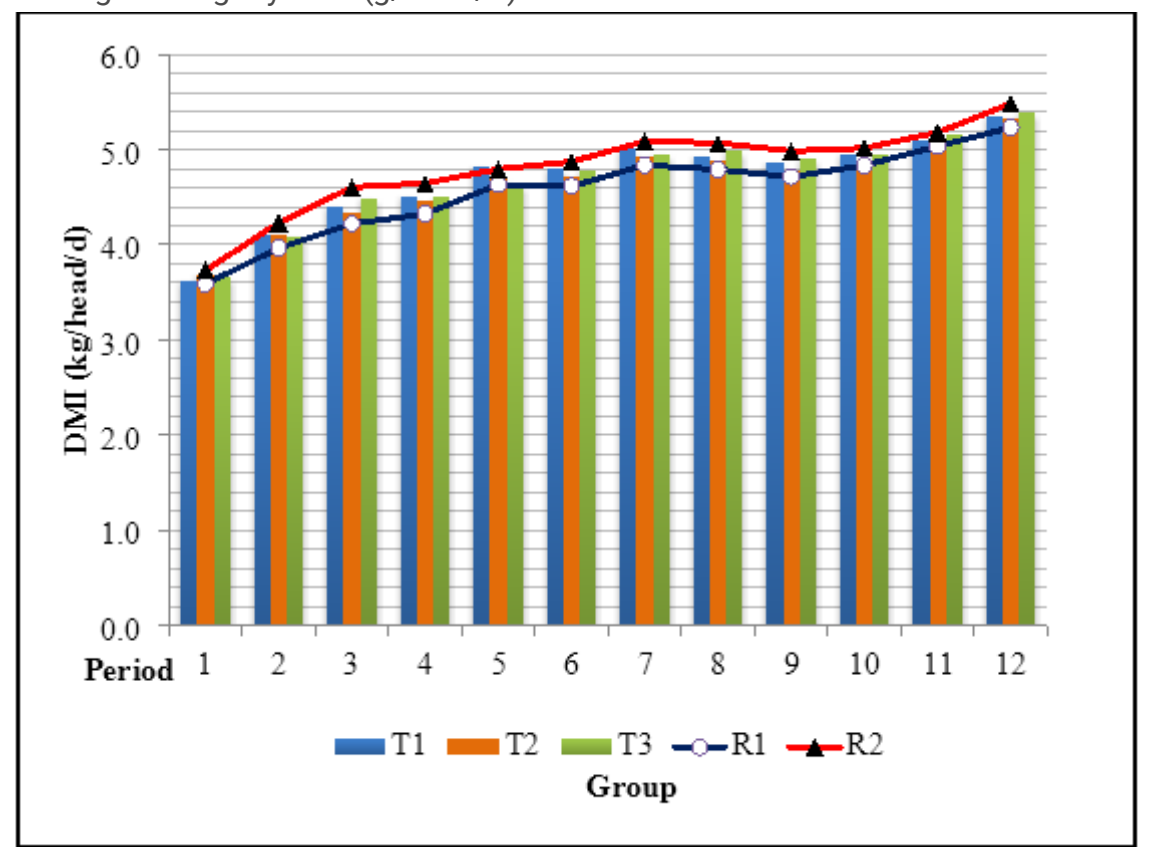

Figure 3

Average fortnightly DMI (kg/head/d) of crossbred heifers

Figure 4

Average fortnightly DMI (kg/100kg BW) of crossbred heifers 


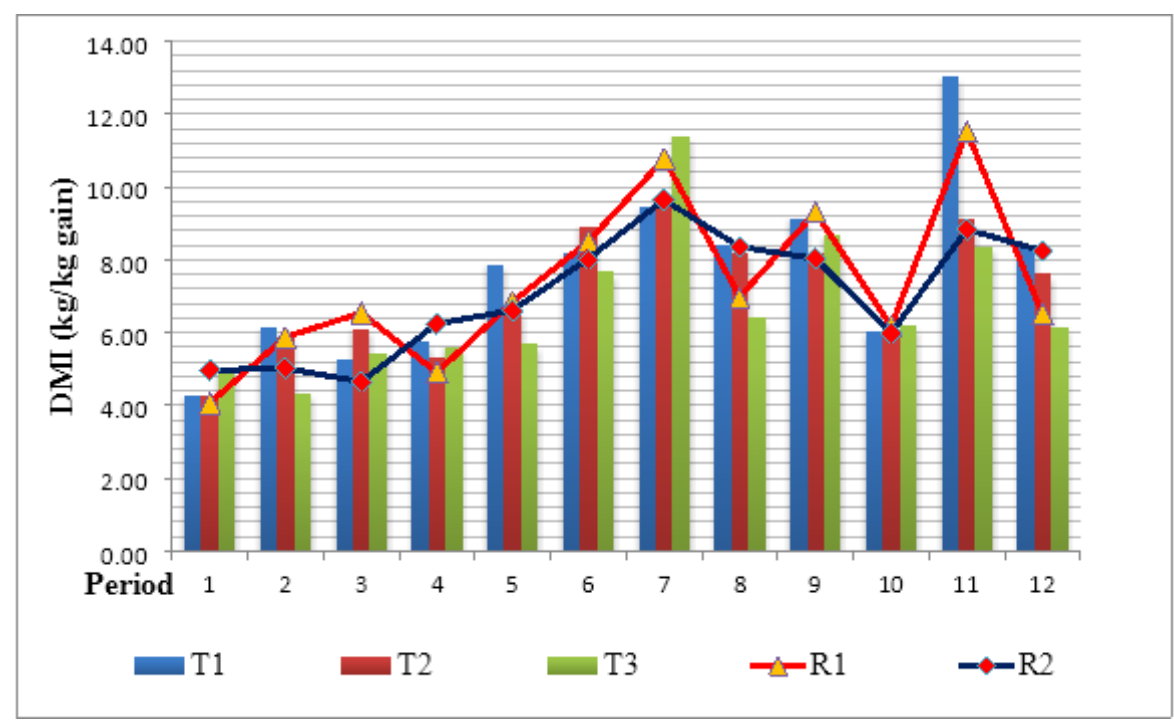

\section{Figure 5}

Average fortnightly DMI ( $\mathrm{kg} / \mathrm{kg}$ gain) of crossbred heifers

\section{Figure 6}

Average triiodothyronine $(\mathrm{ng} / \mathrm{mL})$ of crossbred heifers at different days of experiment

\section{Figure 7}

Average Thyroxine $(\mathrm{ng} / \mathrm{mL})$ of crossbred heifers at different days 